\title{
HEALTH LIFESTYLES IN RUSSIA AND THE SOCIALIST HERITAGE
}

William C. Cockerham, M. Christine Snead, and Derek F. DeWaal

University of Alabama at Birmingham, USA

For some historians, centuries are not precisely bounded by their round centennial dates; rather, their boundaries are defined by their long-term social, political, and cultural processes (Lukacs 1993). In this context, the momentous peacetime collapse of socialism in the former Soviet Union and Eastern Europe between 1989-1991 can be said to mark the termination point of the twentieth century, even though there was almost another decade left to go. This event signaled the end of the world's first socialist state and its demise as the great polarizing force of twentieth century global politics (Malia 1994). The collapse was so complete, described by some scholars as the structural equivalent of defeat in total war, "that Russia and the world, for the indefinite future, will be as engrossed with the consequences of the disaster as they once were with the vicissitudes of the experiment" (Malia 1994:2).

One major consequence is the downturn in life expectancy that accompanied mature Soviet-style socialism. With the exception of East Germany, where the decline did not appear until very late in the 1980s, male longevity began to fall throughout the Soviet bloc in the mid-1960s (Bobak and Marmot 1996; Cockerham 1997, 1999, 2000a; Field 1995, 2000; Häussler, Hempel, and Reschke 1995; Janeĉková 2001; Ostrowska 2001; Shkolnikov 1997; Tulchinsky and Varavikova 1996). Female life expectancy generally stagnated or advanced slightly compared to the West. The steepest decline was in Russia. As shown in Table 1, Russian male life expectancy stood at 64.0 years in 1965 but steadily decreased to 61.7 years by 1980 . Male longevity improved during Gorbachev's 
brief (1984-87) anti-alcohol campaign, reaching 64.9 years in 1987, and then entered a period of accelerated decline — centered around the fall of the communist regime-in which life expectancy fell to a modern low of 57.6 years in 1994. After a short recovery reaching 61.8 years in 1998, male life expectancy turned downward again. The most recent figures for 2000 show Russian males living 58.9 years on average-some 5.1 years less than in 1965. For females, Table 1 shows Russian women lived 72.1 years in 1965 and 71.8 years in 2000. Only 76.2 percent of Russian men and 91.3 percent of women currently reach the age of 50 years (Goskomstat 2000). This situation occurred even though Russia, the dominant state of the former Soviet Union, was not involved in a major war and was a military superpower with a stable government, industrial economy, and free medical care.

(Table 1 about here)

Several possible causes of Russia's health crisis have been investigated. Infectious diseases, environmental pollution, and medically avoidable deaths have made only minor contributions (Bobak and Feachem 1995; Cockerham 1999; Hertzman 1995). Stressful socioeconomic and psychological conditions—-though potentially important—have not been documented as a major causal agent (Leon and Shkolnikov 1998; Siegrist 1996, 2000). A policy failure to address chronic diseases is a likely contributing factor, as the Soviet health care system lacked the flexibility administratively and structurally to adjust to health problems that could not be handled by the mass measures successful in 
controlling infectious ailments (Field 2000). Policy, however, did not cause increased chronic disease; rather, it failed to contain it.

Several studies identify negative health lifestyles as the primary social determinant of the decline in life expectancy in the former socialist nations (Adevi et al. 1997; Cockerham 1997, 1999, 2000a; Ginter 1997; Janeĉková 2001; Janeĉková and Hnilicová 1992; Kulin and Skakkeback 1995; Ostrowska 2001). The health lifestyle literature on Russia specifically describes an entrenched pattern of excessive alcohol consumption, heavy smoking, high fat diet, and lack of health-promoting exercise (Cockerham 1999, 2000a; Palosuo 2000; Palosuo et al. 1998). These lifestyle practices are especially characteristic of middle-age, working-class males, whose high mortality rates from heart disease, alcohol poisoning, and alcohol-related accidents are largely responsible for the decline in male longevity (Carlson and Vägerö 1998; Chenet et al. 1998; Cockerham 1999, 2000a; Notzon et al. 1998).

It is the purpose of this paper to examine whether there is a relationship between health lifestyles in contemporary Russia and attitudes toward the former socialist system in that country. We believe that Soviet-style socialism had the potential to induce passivity on the part of many individuals toward health promotion. Our strategy to investigate this possibility in present-day Russia is to examine the health practices of a national sample of Russian respondents who wish to return to socialism as it was before Gorbachev. We compare this group to those who do not wish to return to socialism and 
favor either staying with the present political and economic course or adopting other reforms. We want to determine if respondents favoring a return to a socialist state have less healthy lifestyles than those who reject socialism, or whether political ideology does not matter. There is no prior research on this topic supported with data, and this paper represents an initial exploration of the question.

Given that overall trends in Russian health lifestyles are negative, we do not expect differences between anti-socialists and pro-socialists in which one group or the other exhibits dramatically more healthy ways of living. However, contemporary Russian psychology identifies a concept "Homo Soveticus," which is defined as a person with a collectivist orientation who does not like to assume any individual responsibilities (Kon 2000). We believe this term is most applicable to pro-socialists, and we investigate whether or not the pattern of health lifestyles for this group is significantly worse than that of anti-socialists. If a socialist heritage negating individual health promotion is operative in Russian society, as some suggest (Dmitrieva 2001; Shkolnikov and Meslé 1996), we would predict that those in favor of returning to socialism would be especially passive with respect to positive health lifestyles. We will begin with a theoretical statement, followed by an examination of socialism under the Soviets and the resulting health lifestyle, a discussion of the post-socialist situation, a description of our methods and data, a presentation of our findings, and a conclusion in which we assess the role of a socialist heritage in present-day health practices. 


\section{THEORETICAL PERSPECTIVE}

Health lifestyles are collective patterns of health-related behavior based on choices from options available to people according to their life chances (Cockerham 2000b). This definition reflects Weber's central contribution to lifestyle theory, which holds that choices and life chances interact with one another in a dialectical fashion, with choices constrained by chances and likely to be consistent with the capability to realize them. Choices are a form of agency (the process by which individuals critically evaluate and choose their course of action), while life chances are a proxy for structure. In a Weberian context, life chances are primarily socioeconomic, but more modern accounts include stratification variables like age, gender, and ethnicity (Cockerham 2000b; Cockerham et al. 1997). In a communist society, the choices of individuals were confined to a singular social and political realm, that of socialism, and expected to conform to the ideology it represented. A dominant political ideology may therefore qualify as another type of life chance.

The dominant ideology thesis in sociology maintains that all societies based on class divisions have a dominant class controlling political ideology and material production (Abercrombie, Hill, and Turner 1980). The ideology operates to penetrate the consciousness of both the dominant and subordinate groups and classes who are encouraged to experience reality through its conceptual framework. A dominant ideology becomes a source of social power when it offers plausible solutions to problems cutting 
across class boundaries and claims to represent the "truth," as in the case of both capitalism and socialism (Mann 1993). In an autocracy, the dominant ideology is aligned with political elites and the state as official doctrine intended to regulate behavior. Durkheim (1897) helps us to recognize that when a situation of over-regulation exists, as in the former Soviet Union, the fall of that system and its replacement with a different social structure may lead to conditions of under-regulation or anomie rather than a restoration of balance. Under such circumstances, individuals and groups, particularly those disadvantaged by the new system, may remain attached to their former norms, values, and ideological orientation.

Whereas Durkheim contributes to our understanding of the social conditions of postsocialism, we suggest that the manner in which ideology is operationalized in the thinking of the individual is best explained by Bourdieu's $(1977,1984,1990)$ concept of habitus. Bourdieu conceptualizes the habitus as a cognitive map or organized framework of perceptions that guides and evaluates behavioral choices and options. He maintains that the internalization of social structures, conditions, and relations in a person's life, as experienced from a particular social position, produces enduring dispositions (a habitus) toward action that are more or less routine. When these dispositions are acted upon they tend to reproduce the structures from which they are derived. The dispositions produced are typically compatible with the parameters imposed by the larger social order that set the individual on a stable and consistent course of behavior. Bourdieu (Bourdieu and 
Wacquant 1992) explains that this process is not a case of pure rational choice because the choices made are not completely autonomous. People may have control over their choices, but not necessarily over the social and psychological conditions channeling those choices in a certain direction.

The habitus provides "a sense of the game" in that it adjusts aspirations and expectations according to the person's objective probabilities of success or failure. Bourdieu observes that this is a practical rather than conscious adjustment as he seeks to move theoretically beyond normative (conscious, rational) explanations of behavior to also encompass actions that are more or less intuitive. The habitus, in this scheme, is a process by which a set of norms and conventions is converted into a mental framework of dispositions and expectations practically oriented toward certain implicit goals.

Unhealthy lifestyle practices in Russia can be seen as reflecting a habitus derived from both socialization in a Soviet state and life experiences. In this situation, a habitus produces an enduring predisposition toward an unhealthy lifestyle that becomes routine and, when acted out regularly over time, reproduces itself. While it may be argued that such a habitus is ultimately harmful, the dispositions it produces may nevertheless be reproduced and become a self-fulfilling prophecy by which individuals adapt to limited opportunities. Bourdieu (1977), for example, describes instances in which structural dispositions (i.e., low educational aspirations of French working-class youth) are transmitted intergenerationally through socialization and continue to produce forms of 
self-defeating behavior. We believe this is the case for health lifestyles in Russia, and we investigate whether past socialist ideology is an important structural variable in this development.

\section{SOVIET SOCIALISM AND HEALTH LIFESTYLES}

According to Malia (1994), socialism originates in a moral idea, that of equality, and culminates in a practical program - the end of private property and the free market. Any measures short of this are not full socialism. Although there are many variants of socialism, its fundamental goal is the creation of a society in which there is maximum equality of access to economic resources, knowledge, and political power, and the minimum possible domination by one group over others (Bottomore 1984). The most obviously unique characteristic of a socialist economy is the replacement of individual private property (except for personal items) with some form of collective (usually state) ownership (Szelenyi, Beckett, and King 1994). The unpredictability of the marketplace is replaced by long-term central planning setting rational objectives and allocating resources on an equitable scale. The state acts on behalf of workers and others to eliminate the class system and redistribute goods and services equitably, thus ending the socioeconomic basis for exploitation, alienation, oppression, and injustice.

This utopian vision was altered by the Soviet version of socialism in which the Communist Party subverted the state to its control and established a totalitarian political system of rule from above (Dahrendorf 1990; Medvedev 2000). This situation essentially 
turned Marx's sociology on its head (Malia 1994). Marx maintained that the "base" of society (the totality of the dominant relations of production) determined the character of its "superstructure" (its ideological and other relations, social consciousness, the state, political parties, and the like). Under the Soviets, however, the superstructure in the form of the party-state determined the base, rather than the other way around. The Communist Party, states Malia (1994), made a "mistake of Columbus" in that it had set sail for a new world (socialism) but instead stumbled on Sovietism as an inverted modernity of partystate domination.

Consequently, Malia (1994) maintains that the Soviet world was not in the first instance a society; rather, it was an ideocratic regime. The basic social unit was not the individual, but the collective ("kollektiv") which was a culturally specific phenomenon existing almost exclusively in Soviet society (Shlapentokh 1989). Collectives were units of colleagues in factories, farms, offices, and schools oriented toward the goals of the wider society (as defined by the party-state), namely, the higher cause of communism. These collectives engaged in mutual surveillance, communal evaluations, admonitions, and recognition of services, and promoted self-analysis and self-criticism; by 1984, there were over two and a half million collectives in the Soviet Union (Shlapentokh 1989). Although collectives provided a monolithic image of social unity at the surface, there was a very fluid core beneath them, as informal face-to-face networks of trusted and reliable friends, relatives, and co-workers took on greater importance as a basis for personal 
social support (Kharkhordin 1999). Such networks were often useful in navigating successfully through the health care delivery system (Rose 2000).

Nevertheless, collectives were a major social mechanism through which the regime induced public conformity and denigrated individualism. "Undoubtedly," states Medvedev (2000), "the totalitarianism of past decades produced forms of consciousness corresponding to the social 'being' of those times" (p. 65). This consciousness included acceptance of an abridgement of personal freedom and initiative in return for state patronage (Bauman 1992). The result, as Medvedev (2000) explains, is that, in the public mind, the interests of the collective and the state ranked higher than those of the individual, collectivism and solidarity were valued more highly than individualism, and the idea of the value and importance of the individual remained an abstraction without specific content. The influence of this ideology was pervasive, concludes Medvedev (2000): "Only idealists and adventurers out of touch with reality, could propose that all we need to do is break up the totalitarian structures and institute democratic mechanisms and the market, and then the previously shackled creative powers of the Russian people would automatically move the country's economy and culture forward and change life for the better" (p. 65).

Kharkhordin (1999) found that collectives promoted individualization, not individuality. He argues that the collectivist practice of self-criticism and striving for selfperfection caused Party members and other citizens to reflect on themselves and to care 
about the possession and development of an individual self. "But this intensification of relation with the self," states Kharkhordin (1999), "proceeded without the concomitant assertion of the values of individual autonomy and private life, since such statements were hardly possible in official discourse" (p. 5). Even though self-awareness developed among individuals, the political ideology of the Soviet system officially de-emphasized the value of the individual, personal autonomy, and the notion of privacy.

Another factor undermining individuality was state patronage. "Under the rule of the patronage state," comments Bauman (1992), "freedom of individual choice in all its dimensions was to be permanently and severely curtailed, yet in exchange the less prepossessing aspects of freedom-like individual responsibility for personal survival, success, and failure-were to be spared" (p. 162). The state provided for the needs of the individual, and the individual, in turn, gave up personal reliance and freedom. To many, observes Bauman, the state was a shelter. Health care and education were free, while old-age pensions and low-cost housing and food, along with guaranteed employment, were state benefits. The Soviet system provided modest but predictable services. However, its totalitarian nature and paternalism has been cited as responsible for the development and spread of a psychology of passivity and irresponsibility (Shkolnikov and Malkov 2000). As Shkolnikov and Meslé (1996) explain, the priority of state aims and interests over personal needs and desires taught people that their individual values 
were of minor importance and there was little reason to pay much attention to their health. If they got sick, the government would take care of them.

An adverse psychosocial environment constraining innovation, creativity, and life satisfaction may also have promoted feelings of apathy, alienation, and low sense of control contributing to a disregard for individual health promotion (Bobak et al. 1998, 2000; Palosuo 2000; Shkolnikov and Malkov 2000). When gender differences are considered, for example, men may have suffered greater apathy than women because of low rewards in the socialist workplace that affected them more (Siegrist 1996, 2000). However, both sexes would have experienced similar macro-level stresses in the workplace, including job insecurity, layoffs, and loss of income during the transition to capitalism. Research from the Czech Republic shows that the stress of men and women workers was about the same during the economic transition in that country (Hraba et al. 1996). Ultimately, the principal difference between the sexes comes down to a more negative health lifestyle for adult males: men excessively drink alcohol and smoke more than women, while women eat a healthier diet (Carlson and Vågerö 1998; Cockerham 1999, 2000a; Hurt 1995; Lopez 1998; Palosuo 2000; Palosuo et al. 1998; Ryan 1995; Shapiro 1995; Shkolnikov and Nemtsov 1997).

In sum, the social and psychological conditions engendered by socialism constrained the practice of positive health lifestyles. As Watson (1995) observes, tradition in late socialism was becoming entrenched, coping strategies were fixed, and lifestyle choices 
intended to create new ways of living were unavailable. "Choices made at the level of the individual," states Watson (1995), "were socially structured by the resources and options available, and the perceptual frameworks to which such arrangements gave rise" (p. 933). In the case of the Soviets, dietary options were limited, especially in the winter, and voluntary participation in leisure-time exercise (the most beneficial for cardiovascular systems, since it is less wearing and stressful than heavy manual labor or dealing with deadlines) was uncommon for the bulk of the population. Russians had limited individual autonomy in choosing positive health behaviors because (1) the partystate did not encourage such activities; (2) the capability of choosing was severely undermined by a lack of choices; (3) male interpersonal socializing centered on negative health practices, especially high alcohol consumption and smoking; and (4) the prevailing policy orientation was to invest responsibility for health in the state rather than the individual.

\section{POSTSOCIALISM AND HEALTH LIFESTYLES}

Health lifestyles in a society featuring high levels of patronage fostering dependency on the state and discouraging individual initiative in daily life are not likely to feature a strong sense of personal responsibility for health (Cockerham 1999). Nor was this sense of responsibility likely to appear quickly in the immediate aftermath of socialism's fall, when alternative mechanisms of support were not readily available and established norms for health promotion were lacking. While the state had assumed responsibility for health 
under the Soviets, it did not meet its obligations as seen in low government budgets for health care, policy neglect of chronic diseases, and substandard facilities—all which worsened when the socialist system imploded in 1991. Shkolnikov and Meslé (1996) comment on this situation:

Many people believed the state would help them in case of a serious health problem or any other disaster. Their resulting careless lifestyle has become especially dangerous under the new circumstances, when the general weakness of the Russian state has made its social and health efforts even more inadequate than in previous years. (p. 145)

The relative passivity of many Russian people toward their health is seen in the few existing studies on this topic. For example, in a comparison of the health lifestyles of people in Helsinki and Moscow, Palosuo and her colleagues (Palosuo 2000; Palosuo et al. 1998) characterized the Moscow lifestyle as "passive" and "unhealthy." Elsewhere, in the Tumenskaya region, a large proportion (nearly 40 percent) of people indicated that their health depends primarily on the health care system rather than themselves (Gubin 1999). In Rostov, research shows that almost all cancer patients (94 percent) in one study expected favorable conditions after surgery and had no plans to do anything themselves to promote their health; instead, they were going to rely solely on medical professionals (Sidorenko and Maksimov 1988). In Kazan, Nazarova (2000) found that most workers did not take care of their health and that many were unable or unwilling to leave jobs 
with hazardous working conditions. Dmitrieva (2001) concludes that self-protective behavior is atypical for Russians, and health is considered to be a functional characteristic (the ability to work), not a value. "The lack of self-protective culture in Russia," concludes Dmitrieva (2001), "is a result of Soviet times that neglected the individual, its life, and, consequently, its health" (p. 326).

The economic downturn that occurred with the end of socialism was accompanied by reduced living standards for most of the population and drastic reductions in social welfare programs, while unhealthy lifestyles continued (Cockerham 1999; Dmitrieva 2001; Medvedev 2000). According to Medvedev (2000), the high mortality rate cannot be explained by economic factors alone; rather, he ranks national peculiarities of diet and lifestyle as particularly important. Walberg et al. (1998) found that the steep decrease in life expectancy in the early 1990s was not due to impoverishment since the greatest rises in mortality were in the wealthiest regions (e.g., Moscow, St. Petersburg, Archangelsk, Karelia, Murmansk, Pskov, Tula) of Russia which experienced the smallest subsequent declines in household income. They also suggest that alcohol consumption was far more important than the rapid pace of change and high unemployment in explaining regional differences in mortality in Russia. In fact, Bobak et al. (1999) state that drinking behavior seems unrelated to individual perceptions of recent societal changes. The number of binge (heavy episodic) drinkers also appears to be large regardless of the economy, and the acute effects of binge drinking in particular have been identified as responsible for a 
substantial number of cardiovascular deaths among young men (Bobak et al. 1999; Chenet et al. 1998).

Medvedev observes that although the purchasing power of the average wage fell by nearly one-half in 1992-93, relative to vodka it increased three times as the government ended its monopoly on vodka production, allowed unrestricted sales from sources at home and abroad, and consumer costs dropped significantly. In 1994, Russia had the highest per capita consumption of pure alcohol in the world-14.5 liters per annum. When it is noted that adult males consume 90 percent of the alcohol in Russia, yet comprise 25 percent of the population, it is apparent that the drinking practices of this group far exceed per capita consumption and reflect a tremendous concentration of drinking. Medvedev (2000) claims that, in view of the country's economic woes, lower alcohol costs were a conscious attempt by the Yeltsin government to calm social discontent by making alcohol affordable by those in even the poorest social strata. Yeltsin (2000) himself notes that the Russian lifestyle dictates that it is impossible not to drink on certain occasions like birthdays, weddings, and socializing with coworkers.

While the amount of taxed alcohol consumed in Russia is about seven liters of pure alcohol per capita, the real figure is at least 14 to 15 liters when the consumption of unregistered imports and home distilled beverages are taken into account (Treml 1997). Even this amount is understated given the significant consumption of ethanol, industrial alcohols, and alcohol substitutes like after-shave lotions and colognes. There is evidence 
that male drinkers consumed more alcohol in the late 1990s than they did in the early part of the decade, although the prevalence of drinkers was smaller (Zohoori et al. 1999). The latter finding may be due to the high mortality among drinkers; nevertheless, it suggests that smaller numbers are drinking increasingly more alcohol. Not only does total per capita consumption of alcohol exceed that of Western countries, but the type of alcohol typically consumed (vodka) and the drinking style (oriented toward drunkenness, binge drinking) are more harmful. Additionally, the cardioprotective features of alcohol do not seem to apply to the Russian population, most likely because of the high prevalence of associated risk factors (Deev et al. 1998).

Cigarette consumption is also higher in Russia than in the West, and male deaths from lung cancer are extremely high by international standards (Lopez 1998; McKee et al. 1998). Whereas smoking as a cause of death is relatively uncommon for Russian women, smoking accounts for over half of all cancer mortality for men (Lopez 1997). As for nutrition, the Russian diet has changed considerably since the 1960s, moving away from the consumption of cereals and potatoes toward much greater consumption of sugar and red meat. By 1990, over 36 percent of Russian food provided energy from fat, making it one of the fattiest diets in the world (Popkin et al. 1997). Furthermore, within families, men consume about fifty percent more fat than women, whose diet tends to be healthier (Shapiro 1995). There are few data on exercise, but what there are show exercise to be 
minimal (Palosuo 2000; Palosuo et al. 1998). Negative health lifestyles therefore continue on a wide scale and remain most characteristic of males.

\section{DATA AND METHODS}

Data were collected through personal interviews in 1998 by the Russian Longitudinal Monitoring Survey, a series of nationally representative surveys of the Russian Federation. The survey is a cooperative effort between the Carolina Population Center of the University of North Carolina at Chapel Hill, the Institute of Sociology of the Russian Academy of Sciences, Paragon Research International, and the Institute of Nutrition of the Russian Academy of Medical Sciences (Zohoori et al. 1999). The data set (Round 8) analyzed for this paper consists of 8,701 adults.

The sample was 57 percent female and 43 percent male. Ages range from 18 to 97 years, with a mean of 42 years. Some 56 percent of the respondents were married, and 44 percent were single, widowed, or divorced. The mean for education was that of a professional/technical trade/factory school graduate without a secondary education. The median household income for the last 30 days computed at the exchange rate for the period was 350 rubles $(\$ 99.92)$, while the mean was 545 rubles $(\$ 155.60)$.

Seven exogenous variables were employed in the analysis. (1) Gender, coded as female $=0$, male $=1$; (2) age, coded in years; (3) education, coded under a Russian system by type of formal schooling attended, as no professional courses $=0$, professional courses (e.g., tractoring, chauffering, typing) $=1$, professional/technical trade/factory 
school without secondary education $=2$, professional/technical trade/factory school with secondary education $=3$, technical, medical, music, pedagogical, art school $=4$, institute, university, academy $=5$, and graduate school, medical residency $=6$; (4) monthly income, coded as none $=0,1$ to 400 rubles $=1,401$ to 800 rubles $=2$, and over 800 rubles $=3$; (5) marital status, coded as not married $=0$, married $=1 ;(6)$ employed, coded as unemployed $=0$, employed $=1$; and (7) socialism, coded as "stay on the present course" and "repair, adjust the present course" = 0 and "return everything to how it was before Gorbachev, to socialism" $=1$. The last item was used for the first time in Round 8 of the RLMS.

Five health lifestyle dependent variables were arranged into a dichotomous format. Alcohol is coded as nondrinker $=0$, drinker $=1$. Frequent drinker, which measures the frequency of alcohol consumption among drinkers only, is coded as drink 2-3 times a week or less $=0$, drink 4-6 times a week or daily $=1$. Smoking measures use of cigarettes and is coded nonsmoker $=0$, smoker $=1$. Exercise measures leisure-time (recreational) exercise. Respondents were requested to not count their physical activities at work, since exercise in the workplace can be associated with stress and demanding tasks, schedules, pressure, and exertion. Exercise is coded no exercise $=0$, exercise $=1$. Preventive checkups asks the respondent whether, in the last three months, he or she has visited a medical institution or specialist not because of sickness but for a preventive checkup; responses are coded no $=0$, yes $=1$. 
Two additional measures of health—overweight and health status—are included in the analysis. Overweight is based on Body Mass Index scores and is coded 24 and under $=0$, 25 and over $=1$. The Index measures the ratio of weight (in kilograms) to height (in meters) and is typically used to determine healthy weight ranges. Higher than average scores are indicators of being overweight. Positive scores for adult men and women are in the 19-22 range, while 25 and over signifies being noticeably overweight. The mean score for the sample as a whole is 25.7 and the median is 24.8 . For men, the mean score is 24.5 and the median is 24.1 ; for women, the scores are 26.6 and 25.6 , respectively. Health status is a subjective self-ranking of one's own health. Health status is coded very bad and bad $=0$, average, good, and very good $=1$.

Table 2 shows the distribution of the dependent and independent variables in the analysis. The data were analyzed using logistic regression, and the results are shown in Tables 3 and 4. The statistic presented is the odds ratio, which measures the direction and magnitude of the relationship between an independent and dependent variable. The 95 percent confidence intervals associated with the odds ratios are also reported.

(Table 2 about here)

\section{RESULTS}

Odds ratios and confidence intervals obtained from the regression analyses for the five health lifestyle variables are shown in Table 3. Alcohol, the first variable displayed, is significantly associated with all of the independent variables at the .001 level. Anti- 
socialists are significantly more likely to drink alcohol than pro-socialists, as are males, younger persons, married respondents, those with higher education and incomes, and the employed. Males are nearly $2 \frac{1}{2} 2$ times more likely to be drinkers than females. Although younger people are more likely than older people to drink, it should be kept in mind that the average age in this sample is 42 years. The results for age therefore reflect predominately middle-age practices. Although respondents with higher levels of education are also more likely to drink, the mean score for education is 2.64 , which indicates that the average respondent has slightly better than professional/technical trade/factory school training without completion of secondary education. Consequently, the education level of many higher educated persons in this sample is not very high.

(Table 3 about here)

Another important indicator of alcohol consumption is frequency of drinking. Frequent drinking, viewed in light of the Russian male drinking style, does not suggest moderate consumption. As Bobak and Marmot (1999) point out, "findings in western populations may not be extrapolated to the levels and patterns of alcohol consumption, as well as the quality of alcohol consumed in Russia" (p. 337). There is no evidence that frequent drinkers in Russia do not also binge drink or that binge drinkers drink infrequently. There is evidence that only moderate drinking on a daily basis is atypical (Bobak et al. 1999), episodes of binge drinking have become more frequent (McKee, Shkolnikov, and Leon 2000), and that overall levels of consumption have increased 
(Zohoori et al. 1999). While frequency of drinking may not be the optimal measure of unhealthy drinking, it is nonetheless suggestive of heavy consumption in Russia.

Table 3 shows that among those who drink, pro-socialists are nearly $1 \frac{1}{2} 2$ times more likely than anti-socialists to be frequent drinkers. Furthermore, males are nearly 6 times more likely than females to drink frequently, while age produces a significant difference as well, in that older-rather than younger-persons drink more frequently. The profile of a typical frequent drinker that emerges from these data is that of an older, pro-socialist male.

The results for smoking in Table 3 show that socialism is not a significant variable. However, males are over 16 times more likely to smoke than females. Smokers are also significantly more likely to be younger, married, and with higher incomes. As for leisuretime exercise, Table 3 shows that anti-socialists are significantly $(\mathrm{p}<.001)$ more likely to exercise. Being pro-socialist decreases the odds of exercising by an impressive 48 percent. The other independent variables are also significant in relation to exercise at the .001 level: Males are more likely to exercise, as are younger people, unmarried respondents, persons with higher incomes and education, and the unemployed. Yet only 21 percent of this sample engage in any type of leisure-time exercise, with most doing only light exercise. Table 3 also shows that anti-socialists are also significantly $(\mathrm{p}<.001)$ more likely to have preventive checkups. Moreover, females are more likely than males 
to have such checkups, while younger persons and those with higher education and incomes are more likely to do the same.

Table 4 shows that socialism makes no difference with respect to being overweight, but females are more overweight than males, older persons are more overweight than younger people, and married persons, along with those with higher incomes and employment, are significantly more overweight than their counterparts. The results for self-ranked health status are also shown in Table 4. Anti-socialists, as compared to prosocialists, rate their health significantly better. Despite their higher mortality rates, males rank their health significantly better than females, and younger persons, those with higher educational levels, and the employed do likewise.

(Table 4 about here)

The variable of greatest interest for this analysis is socialism, which compares those who wish to return to socialism as it was before Gorbachev to those who do not. The sociodemographics of those who favor a return to socialism show that the respondents in this group are older, with an average age of 48.6 years, compared to 37.9 years for those who reject socialism. There are more women (59 percent) than men (41 percent) among those who favor socialism, but the sex difference is not as great among the anti-socialists (54 percent women and 46 percent men). The same percentage of pro-socialists (57.8 percent) and anti-socialists (57.8 percent) are married, while the pro-socialists have a much larger percentage of widows/widowers (18.2 percent versus 6.8 percent). A 
particularly striking characteristic of the pro-socialist group is that some 59.5 percent are without work or paid leave as compared with 43.6 percent of the anti-socialists. As for education, fully one-third of the pro-socialists (33.5 percent) are in the lowest educational category (no professional courses), and approximately one-half (49.1 percent) are in the lowest two categories (no professional courses/professional courses in tractoring, typing, etc.). Overall, the anti-socialists are much better educated, with only 25 percent in the lowest two educational categories and some 54.6 percent (compared to 28.4 percent) in the highest three categories.

The results show that anti-socialists are more likely to be drinkers, but pro-socialists drink more frequently. Since drinking is common among males, the proportion of prosocialist drinkers may have been influenced by the greater preponderance of women in this group. Moreover, the ranks of potential pro-socialist male drinkers in the sample may have been reduced by mortality. As the pro-socialists are some eleven years older on average than the anti-socialists, many male drinkers formerly in this group may have already died. Of greater importance is the finding that older pro-socialist males are more frequent drinkers than anti-socialists of any age or gender, thereby suggesting a stable and consistent life course of unhealthy repetitive alcohol consumption.

There are no significant differences with respect to smoking and body mass, as both ideological groups smoke and have high body mass scores. However, anti-socialists are significantly more likely to exercise and have preventive checkups. What little exercise 
and preventive checkups are being carried out, these data show that it is the anti-socialists who are doing most of it, in comparison to pro-socialists who do practically none of it. Anti-socialists also rank their health status significantly higher than the pro-socialists.

\section{CONCLUSION}

It is clear that the Soviet government promoted neither individuality nor individual initiative in health matters as they imposed a collective-oriented ideology on the population. Whereas people had the option to accept or reject this doctrine, they were nonetheless confronted with it in daily life and expected to show at least a surface conformity in public settings. The persistence of a "Homo Soveticus" personality type in Russian society today, described as a "collectivist" who rejects individual responsibility supports the notion of a socialist heritage undermining the enactment of positive health lifestyles for many people. If, as it is argued (Dmitrieva 2001; Shkolnikov and Meslé 1996), this heritage has indeed fostered a lack of responsibility for individual health promotion in Russia, then those persons wishing to return to this system would seem most likely to practice a negative health lifestyle. These data suggest that this is indeed the case, as pro-socialist respondents demonstrate less positive health promoting activities than anti-socialists-although neither group collectively practices good health measures. In fact, the extent of negative health practices is so widespread that it can be argued that the health lifestyles of anti-socialists is only marginally better than that of pro-socialists, but it is better nevertheless. 
It is also clear that poor health practices are deeply ingrained in the habitus of many Russians, especially middle-age men with a working-class level of education. This habitus appears highly resistance to changing circumstances, as the old ways of heavy drinking, smoking, and the like are applied to a new situation. If the phrase "socialism is bad for your health" from Soviet times is apt, then the persistent ideological influence of Soviet-style socialism may still be taking a toll on the health of Russians. Considerably more time, widespread health education, and the emergence of younger generations unencumbered with a Soviet-oriented habitus may be needed to reverse the mortality pattern.

Whether or not ideology is usually a major factor in health lifestyle formation cannot be ascertained from these data. It may be that it is important only in a totalitarian partystate scenario. More extensive research is needed to determine the full role of macro-level ideologies in health promotion and lifestyles. Given that positive health lifestyles are more prevalent in liberal democracies promoting a wide range of civil freedoms and individual health options, there may be an important relationship yet to be determined between different types of political ideology and health lifestyles. 
William C. Cockerham is Professor of Sociology, Medicine, and Public Health and CoDirector of the Center for Social Medicine and Sexually-Transmitted Diseases at the University of Alabama at Birmingham. His most recent publications include Medical Sociology, 8th ed. (Prentice-Hall, 2001) and the Blackwell Companion to Medical Sociology (Blackwell, 2001). He co-edited a special issue of Social Science and Medicine (November, 2000) on the health crisis in Russia and Eastern Europe and is participating in a European Union funded study on health and lifestyles in the Commonwealth of Independent States.

M. Christine Snead is a Ph.D. candidate in medical sociology and research assistant in epidemiology and international health in the School of Public Health at the University of Alabama at Birmingham. She is a recipient of a NIH scholarship to conduct research on contraception among couples at high risk of sexually-transmitted infections.

Derek F. DeWaal is a former graduate student in the School of Public Health at the University of Alabama at Birmingham. He is currently employed as a research assistant by the California Department of Corrections in Sacramento. 


\section{REFERENCES}

Abercrombie, Nicholas, Stephen Hill, and Bryan S. Turner. 1980. The Dominant Ideology Thesis. London: Allen \& Unwin.

Adevi, O., G. Chellaraj, E. Goldstein, A. Preker, and D. Ringold. 1997. "Health Status During the Transition in Central and Eastern Europe: Development in Reverse?" Health Policy and Planning 12:132-45.

Bauman, Zygmunt. 1992. Intimations of Postmodernity. London: Routledge.

Bobak, M. and R. Feachem. 1995. "Air Pollution and Mortality in Central and Eastern Europe.” European Journal of Public Health 5:82-6.

Bobak, Martin and Michael Marmot. 1996. "East-West Mortality Divide and Its Potential Explanations: Proposed Research Agenda.” British Medical Journal $312: 421-25$. 1999. "Alcohol and Mortality in Russia: Is it Different than Elsewhere?" Annuals of Epidemiology 9:335-38.

Bobak, Martin, Martin McKee, Richard Rose, and Michael Marmot. 1999. “Alcohol Consumption in a National Sample of the Russian Population.” Addiction 94:857-66. Bobak, Martin, Hynek Pikhart, Clyde Hertzman, Richard Rose, and Michael Marmot. “Socioeconomic Factors, Perceived Control and Self-Reported Health in Russia. A Cross-Sectional Survey.” Social Science and Medicine 47:269-79. Bottomore, Tom. 1984. Sociology and Socialism. Brighton, UK: Wheatsheaf. 
Bourdieu, Pierre. 1977. Outline of a Theory of Practice. Translated by R. Nice.

Cambridge, UK: Cambridge University Press. 1984. Distinction. Translated by R. Nice. Cambridge, MA: Harvard University

Press. 1990. The Logic of Practice. Translated by R. Nice. Stanford, CA: Stanford University Press.

Bourdieu, Pierre and Loïc J. D. Wacquant. 1992. An Invitation to Reflexive Sociology. Chicago: University of Chicago Press.

Carlson, Per and Denny Vågerö. 1998. “Alcohol Abuse. The Social Pattern of Heavy Drinking in Russia During Transition. Evidence from Taganrog 1993.” European Journal of Public Health 8:280-285.

Chenet, Laurent, Martin McKee, David Leon, Valdimir Shkolnivkov, and Sergei Vassin. 1998. “Alcohol and Cardiovascular Mortality in Moscow.” Journal of Epidemiology and Community Health 38:117-130.

Cockerham, William C. 1997. "The Social Determinants of the Decline of Life Expectancy in Russia and Eastern Europe: A Lifestyle Explanation." Journal of Health and Social Behavior 38:131-148. 1999. Health and Social Change in Russia and Eastern Europe. New York and London: Routledge. 2000a. "Health Lifestyles in Russia." Social Science and Medicine 51:1313-24. 
. 2000b. "The Sociology of Health Behavior and Health Lifestyles." Pp. 159-

72 in Handbook of Medical Sociology, edited by Chloe Bird, Peter Conrad, and Allen Fremont, 5th ed. Upper Saddle River, NJ: Prentice-Hall.

Cockerham, William C., Alfred Rütten, and Thomas Abel. 1997. “Conceptualizing Contemporary Health Lifestyles: Moving beyond Weber." Sociological Quarterly $38: 321-42$.

Dahrendorf, Ralf. 1990. Reflections on the Revolution in Europe. New York: Time Books.

Deev, A., D. Shestov, J. Abernathy, A. Kapustina, N. Muhina, and S. Irving. 1998. "Association of Alcohol Consumption to Mortality in Middle-Aged U.S. and Russian Men and Women." Annals of Epidemiology 8:147-53.

Dmitrieva, Elena. 2001. “The Russian Health Care Experiment: Transition of the Health Care System and Rethinking the Sociology of Medicine.” Pp. 320-33 in The Blackwell Companion to Medical Sociology, edited by William Cockerham. Oxford, UK: Blackwell.

Durkheim, Emile. [1897] 1951. Suicide. Translated by J. Spaulding and edited and translated by G. Simpson. New York: Free Press.

Field, Mark G. 1995. "The Health Crisis in the Former Soviet Union: A Report from the 'Post-War' Zone.” Social Science and Medicine 41:1469-78. . 2000. "The Health and Demographic Crisis in Post-Soviet Russia: A 
Two-Phase Development." Pp. 11-42 in Russia's Torn Safety Nets, edited by Mark Field and Judith Twigg. New York: St. Martin's Press.

Ginter, Emil. 1997. "The Influence of Some Factors on the Non-Homogeneity in Adult Male Life Expectancy in the Slovak Republic." Central European Journal of Public Health 5:133-35.

Goskomstat. 2000. The Demographic Yearbook of Russia. Moscow: State Committee of the Russian Federation on Statistics.

Gubin, Alexey. 1999. "Sostoyanie zdorovia naselenia Tumenskoy oblasti” ["Social Health of the Population in Tumenskaya Region"]. SOZIS 7:93-95.

Häussler, B., Elke Hempel, and P. Reschke. 1995. "Die Entwicklung von Lebenserwartung und Sterblichkeit in Ostdeutchland nach der Wende (1989-1992)" ["Life Expectancy and Mortality in East Germany after the Fall of the Berlin Wall (1989-1992)"]. Gesundheitswesen 7:365-72.

Hertzman, Clyde. 1995. Environment and Health in Central and Eastern Europe. Washington, D.C.: World Bank.

Hraba, Joseph, Frederick O. Lorenz, Gang Lee, and Zdenka Pechacova. 1996. "Gender and Well-Being in the Czech Republic." Sex Roles: A Journal of Research 34:517-34.

Hurt, Richard D. 1995. "Smoking in Russia: What do Stalin and Western Tobacco Companies Have in Common?" Mayo Clinic Proceedings 70:1007-11. 
Janeĉková, Hana. 2001. "Transformation of the Health Care System in the Czech Republic-A Sociological Perspective.” Pp. 347-64 in The Blackwell Companion to Medical Sociology, edited by William Cockerham. Oxford, UK: Blackwell. Janeĉková, Hana and Helena Hnilicová. 1992. “The Health Status of the Czechoslovak Population. It's Social and Ecological Determinants." International Journal of Health Sciences 3:143-56.

Kharkhordin, Oleg. 1999. The Collective and the Individual in Russia. Berkeley: University of California Press.

Kon, Igor. 2000. “Promoting Russia’s New Psychology.” The Russia Journal Weekly Supplement 12 (April 3):1-2.

Kulin, Howard E. and Niels E. Skakkeback. 1995. "Environmental Effects on Human Reproduction: The Basis for New Efforts in Eastern Europe.” Social Science and Medicine 41:1479-86.

Leon, David A. and Vladimir M. Shkolnikov. 1998. "Social Stress and the Russian Mortality Crisis.” Journal of the American Medical Association 279:790-91.

Lopez, Alan D. 1997. "Mortality from Tobacco on the New Independent States." Pp. 262-74 in Premature Mortality in the New Independent States, edited by J. Bobadilla, C. Costello, and F. Mitchell. Washington, D.C.: National Academy Press. 1998. "Smoking and Death in Russia." Tobacco Control 7:3-4.

Lukacs, John. 1993. The End of the Twentieth Century and the End of the Modern Age. 
London: Ticknor and Fields.

Malai, Martin. 1994. The Soviet Tragedy: A History of Socialism in Russia, 1917-1991. New York: Free Press.

Mann, Michael. 1993. The Sources of Social Power. Vol. II. Cambridge, UK: Cambridge University Press.

McKee, Martin, Martin Bobak, Richard Rose, Vladimir Shkolnikov, Laurent Chenet, and David Leon. 1998. "Patterns of Smoking in Russia.” Tobacco Control 7:22-26.

McKee, Martin, Vladimir Shkolnikov, and David A. Leon. 2000. "Alcohol is Implicated in the Fluctuations in Cardiovascular Disease in Russia Since the 1980s." Annals of Epidemiology 11:1-6.

Medvedev, Roy. 2000. Post-Soviet Russia: A Journey through the Yeltsin Era.

Translated and edited by G. Shriver. New York: Columbia University Press.

Nazarova, Inna. 2000. "Self-Rated Health and Occupational Conditions in Russia." Social Science and Medicine 51:1375-85.

Notzon, Francis C., Yuri Komarov, Sergei Ermakov, Christopher T. Sempos, James S. Marks, and Elena Sempos. 1998. "Cause of the Declining Life Expectancy in Russia." Journal of the American Medical Association 279:793-800.

Ostrowska, Nina. 2001. "In and Out of Communism: The Macrosocial Context of Health in Poland." Pp. 334-46 in The Blackwell Companion to Medical Sociology, edited by William Cockerham. Oxford, UK: Blackwell. 
Palosuo, Hannle. 2000. "Health-Related Lifestyles and Alienation in Moscow and Helsinki." Social Science and Medicine 51:1325-41.

Palosuo, Hannele, Antti Uutele, Irina Zhuravleva, and Nina Lakomova. 1998. "Social Patterning of Ill Health in Helsinki and Moscow: Results from a Comparative Survey in 1991." Social Science and Medicine 46:1121-36.

Popkin, Barry, Namvar Zohoori, Lenore Kohlmeier, Alexander Baturin, Arseni Martinchik, and Alexander Deev. 1997. "Nutritional Risk Factotrs in the Former Soviet Union.” Pp. 314-34 in Premature Death in the New Independent States, edited by J. Bobadilla, C. Costello, and F. Mitchell. Washington, D.C.: National Academy Press.

Rose, Richard. 2000. "How Much Does Social Capital Add to Individual Health? A Survey Study of Russians.” Social Science and Medicine 51:1421-35.

Ryan, Michael. 1995. "Alcoholism and Rising Mortality in the Russian Federation." British Medical Journal 310:646-48.

Shapiro, Judith. 1995. “The Russian Mortality Crisis and Its Causes.” Pp. 149-78 in Russian Economic Reform at Risk, edited by A. Åslund. London: Pinter.

Shkolnikov, V. 1997. "Smertnost i prodolzhitelnost' zhizni” ["Mortality and Life Expectancy”]. Pp. 113-34 in A. Visherevskiy (ed.), Naseleniye Rossii 1996 [Population of Russia 1996]. Moscow: Tsentr demografii i ekologii cheloveka [Center of Demography and Human Ecology]. 
Shkolnikov, V. M. and L. P. Malkov. 2000. Prodolzhitelnost' zhizni v Rossii [Life Expectancy in Russia]. Moscow: Tsentr demografii i ekologii cheloveka [Center of Demography and Human Ecology].

Shkolnikov, Vladimir M. and France Meslé. 1996. "The Russian Epidemiological Crisis as Mirrored by Mortality Patterns.” Pp. 113-67 in Russia’s Demographic Crisis, edited by Julie DaVanzo. Santa Monica, CA: Rand.

Shkolnikov, Vladimir and Alexander Nemtsov. 1997. "The Anti-Alcohol Campaign and Variations in Russian Mortality.” Pp. 239-61 in Premature Mortality in the New Independent States, edited by J. Bobadilla, C. Costello, and E. Mitchell. Washington, D.C.: National Academy Press.

Shlapentokh, Vladimir. 1989. Public and Private Life of the Soviet People. Oxford, UK: Oxford University Press.

Sidorenko, Y. and G. Maksimov. 1988. "Eticheskij i Deontologicheskii Voprosi v onkologicheskom Stationari” [“Ethic and Deontological Issues in Cancer Clinics”]. Zdravoochranenie Rossiskoy Federatzii 1:83-89.

Siegrist, Johannes. 1996. "High Cost-Low Gain Conditions at Work as a Determinant of Cardiovascular Disease Morbidity and Mortality." Pp. 169-85 in East-West Differences in Life Expectancy: Environmental and Nonenvironmental Determinants, edited by S. Kelley, M. Bobak, and C. Hertzman. Dordrecht, The Netherlands: Kulwer. 
. 2000. "Place, Social Exchange and Health: Proposed Sociological Framework." Social Science and Medicine 51:1283-93.

Szelenyi, Ivan, Katherine Beckett, and Lawrence P. King. 1994. "The Socialist Economic System.” Pp. 234-51 in The Handbook of Economic Sociology, edited by Neil Smelser and Richard Swedberg. Princeton and New York: Princeton University Press and Russell Sage Foundation.

Treml, Vladimir. 1997. "Soviet and Russian Statistics on Alcohol Consumption and Abuse." Pp. 220-38 in PrematureDeath in the New Independent States, edited by J.

Bobadilla, C. Costello, and F. Mitchell. Washington, D.C.: National Academy Press. Tulchinsky, Theodore H. and Elena A. Varavikova. 1996. "Addressing the Epidemiologic Transition in the Former Soviet Union: Strategies for Health System and Public Health Reform in Russia." American Journal of Public Health 86:313-20. Walberg, Peder, Martin McKee, Valdimir Shkolnikov, Laurent Chenet, and David A. Leon. 1998. "Economic Change, Crime, and Mortality Crisis in Russia." British Medical Journal 317:312-18.

Watson, Peggy. 1995. "Explaining Rising Mortality among Men in Eastern Europe.” Social Science and Medicine 41:923-34.

Weber, Max. [1922] 1978. Economy and Society, 2 vols., edited and translated by G. Roth and C. Wittch. Berkeley: University of California Press.

Yeltsin, Boris. 2000. Midnight Diaries. Translated by C. Fitzpatrick. New York: 
PublicAffairs.

Zohoori, Namvar, Laura Henderson, Karin Gleiter, and Barry Popkin. 1999.

"Monitoring Health Conditions in the Russian Federation: The Russia Longitudinal

Monitoring Survey 1992-98." Chapel Hill, NC: Carolina Population Center,

University of North Carolina at Chapel Hill. 